\title{
The indigenous participation as a pathway to decoloniality in a developing world: a reading from the constitutional jurisprudence in Colombia
}

\author{
La participación indígena como camino a la \\ decolonialidad en un mundo en desarrollo: una lectura \\ desde la jurisprudencia constitucional en Colombia
}

\author{
Carlos Daniel Muñoz Chamorro \\ Master's in Latin American and Caribbean Studies \& International \\ Development Studies University of Guelph, Canada \\ Associate Researcher of the Derecho, Justicia y Región Research Group, \\ cdmunoz@udenar.edu.co.cmuozcha@uoguelph.ca
}

\section{Abstract}

Although development is a complex economic, social, cultural, and political process aimed at the constant improvement and well-being of the entire population, in many cases, it is equated with economic growth only. Focusing exclusively on this type of development, contributes to the strengthening of the economic growth of dominant economies and dismisses the local needs and knowledge of the indigenous peoples in the territory where these development projects

\footnotetext{
Cómo citar este artículo:

Muñoz Chamorro, C. (2021). The indigenous participation as a pathway to decoloniality in a developing world: a reading from the constitutional jurisprudence in Colombia. Revista de la Facultad de Derecho y Ciencias Políticas, Universidad Pontificia Bolivariana, 51(135), pp. 303-325. doi: https://doi.org/10.18566/rfdcp.v51n135.a01
}

Recibido: 09 de junio de 2020.

Aprobado: 06 de abril de 2021. 
are implemented. Based on this perspective, the concept of development becomes a discursive instrument that reflects the evolution from physical colonialism to the coloniality of power. This paper illustrates how in dominant judgments of the Constitutional Court of Colombia, indigenous participation might be a pathway to decoloniality. To reach this conclusion, this paper is divided into three sections: the first examines the concept of good living ${ }^{1}$ as one of the most significant development expressions of indigenous identity; the second analyzes the notion of good living regarding the concepts of coloniality and development; the third discusses prior consultation and free, prior, and informed consent as fundamental rights and social processes that play a decolonial role in indigenous communities in Colombia.

\section{Keywords}

Development; developing; coloniality of power; free, prior, and informed consent; prior consultation; indigenous communities.

\section{Resumen}

Aunque el desarrollo es un complejo proceso económico, social, cultural y político que tiene como objetivo la mejora constante y el bienestar de toda la población, en muchos casos se equipara con el crecimiento económico únicamente. Centrarse exclusivamente en este tipo de desarrollo contribuye a reforzar el crecimiento económico de las economías dominantes y desestima las necesidades y los conocimientos locales de los pueblos indígenas del territorio donde se ejecutan estos proyectos de desarrollo. A partir de esta perspectiva, el concepto de desarrollo se convierte en un instrumento discursivo que refleja la evolución del colonialismo físico a la colonialidad de poder. Este trabajo ilustra cómo en las sentencias dominantes de la Corte Constitucional de Colombia, la participación indígena puede ser un camino para la decolonialidad. Para llegar a esta conclusión, este trabajo se divide en tres secciones: la primera examina el concepto del buen vivir como una de las expresiones de desarrollo más significativas de la identidad indígena; la segunda analiza la noción del buen vivir en relación con los conceptos de colonialidad y desarrollo; la tercera discute la consulta previa y el consentimiento libre, previo e informado como derechos fundamentales y procesos sociales que juegan un papel decolonial en las comunidades indígenas de Colombia.

\section{Palabras clave}

Desarrollo, en vía de desarrollo; colonialidad del poder; consentimiento previo, libre e informado; consulta previa; comunidades indígenas.

1 El buen vivir, for its reference in Spanish. 


\section{Introduction}

Not only have modern theories of development sought to intervene in the economic basis of societies, but they have also affected, intentionally or not, some components of the social basis of their targeted communities. The application of these modern theories of development has repeatedly produced adverse effects on indigenous peoples because several development projects are related to natural resources over indigenous ancestral lands. Indigenous communities in Colombia have experienced the physical and cultural consequences of development projects over their territories, particularly on the production and exploitation of hydrocarbons (Constitutional Court, 2018, SU123; 2019, T063). The implementation of these type of development projects over indigenous territories has threatened the relationship indigenous peoples have with their natural environment, jeopardizing their way of living and, ultimately, their own identities.

More frequently than not, development practitioners lack the ability to understand that economic growth projects do not always coincide with the concept of human development (Hartwick \& Peet, 2015). In most cases, development projects are more focused on economic growth than on human development. The definition of human development for indigenous peoples is closely related to good living (Constitutional Court, 2016, T 197). The concept of good living in Colombia is jurisprudentially defined as the interpretation of the world focused on the human being and its relationship with its natural environment. It is a notion that includes the full satisfaction of needs and the respect for Mother Earth: La Pachamama. Good living is a form of spirituality, which implies peace and the construction of a land without evil (Houtart, 2011, pp. 10). It includes being in harmony with oneself and then with all forms of existence. It is made up of physical, psychic, affective, ecological, ethical, aesthetic, productive, spiritual, and political correlations, in which everything living should never be used for commercial purposes, but only to satisfy vital needs of the rest of the living elements (Crespo, 2017, pp. 15).

From a theoretical framework, the imposition of those development projects is known as a new form of colonialism (Mignolo, 2005, pp. 21). Grosfoguel uses the concept of coloniality of power to refer to a pattern of global and continuous domination (2010, pp. 73) with an effect of economic, political, social, and epistemological domination over satellite societies. Indigenous communities are satellite societies defined as societies that have been historically marginalized from the center or the metropolis (Gunder, 1966, pp. 17). To 
tackle this new form of colonialism, it is necessary to find a balance between satellite societies' rights and the interests of central economies through the adequate implementation of development projects. It can be done by creatively designing new and non-external development theories engaging the concept of good living and indigenous development.

The rewriting of the Colombian Constitution in 1991, introduced the indigenous right to participate in public issues. Article 330 of the Constitution states that the exploitation of natural resources in indigenous territories shall be carried out without detriment to the indigenous communities' cultural, social, and economic integrity. In decisions adopted concerning such exploitation, the Government must include the participation of representatives from the respective communities. This right translates into different constitutional levels of participation: prior consultation (henceforth $P C$ ) and free, prior, and informed consent (henceforth FPIC) (Constitutional Court, 2018, T123). PC relates to the right of indigenous communities to be consulted on any decision that could directly affect them; however, indigenous opinion is not binding for the State. FPIC relates to the right of indigenous peoples to decide in three exceptional cases about the implementation of development projects ${ }^{2}$. In free, prior, and informed consent, the execution of the measure requires consent and in the event of not reaching an agreement, the protection of indigenous communities will prevail.

In recent decades, $P C$ and $F P I C$ have become effective legal instruments to protect indigenous ancestral lands, indigenous human development, and the indigenous application of good living. Moreover, the exercise of these rights advocates for the protection of the entire range of fundamental rights of indigenous communities (Inter-American Commission of Human Rights, 2009). $P C$ and FPIC play a vital role in the decoloniality process, especially in terms of preserving indigenous land and identity, arguing that they have the right to participate as a political community in development projects according to their worldview; using their local knowledge; and, exploring local solutions (Edwards, 2008, pp. 120). PC and FIPC have also become an example of resistance to the global north development discourse (Escobar, 2007, pp. 365) as it brings reconciliation between cultural hybridization and indigenous identities: making satellite societies begin to be part of the pivotal governmental decisions without leaving behind their vision of the world.

2 (i) Transfer or relocation of the indigenous or tribal people from their place of settlement; (ii) the storage or deposit of dangerous or toxic materials in their territories; (iii) measures that imply a high social, cultural, and environmental impact that puts their subsistence at risk (Constitutional Court, 2018, T123). 
This paper argues that in dominant judgments of the Constitutional Court of Colombia, the indigenous rights to prior consultation and to free, informed, and prior consent might be considered a pathway to applying the theory of decoloniality. In order to develop this reasoning, this paper is divided into three chapters, as follows: the first will examine the concept of good living as one of the most significant development expressions of indigenous identity; the second will analyze the notion of good living regarding the concepts of coloniality and development; the third will discuss prior consultation and free, prior, and informed consent as fundamental rights and social processes that play a decolonial role in indigenous communities in Colombia.

The methodology of this paper will be developed as follows: (i) Method: hermeneutic and interpretive; it seeks to understand, clarify, and interpret the background of a complex socio-legal phenomenon through the analysis and confrontation of doctrinal and legal content. (ii) The paradigm to address the text will be the historical-hermeneutic paradigm because it will study $P C$ and FPIC as a social and as a legal process that, through its progressive interpretation, regulates current relationships of human coexistence. (iii) This project has qualitative scope since it seeks to identify the attributes of the $P C$ and FPIC, including its definitions, development, applications, factual, and legal requirements in doctrinal and legal content. (iv) The collection of information is exclusively documentary since it selects doctrinal and jurisprudential bibliography to achieve a systematic analysis of the theory and application of the rights to $P C$ and $F P I C$.

\section{El buen vivir and indigenous identity}

Identity is a social construction of how people perceive themselves and how they are perceived within a given collectivity. This section will analyze good living as an expression of indigenous identity and development; then, it will explain interculturality and plurinationality as the foundation for reconciling heterogeneous societies and collective memory.

For Bauman, identity is eminently negotiable and revocable (2004, pp. 32). He states that there is a freedom of identities, and now men and women as individuals can choose them, using their own means and intelligence (Bauman, 2004, pp.68). Although Sachar (2001, pp. 68) defends the idea of the existence 
of a right to exit ${ }^{3}$, which implies that people who identify as a member of a group can leave it anytime, Holzeleithner (2012, pp. 28) argues that belonging to a community is not optional, but there is a binding reason why people get to be part of that identity. The 169 Convention (International Labour Organization, 1989) seems to be more aligned with Holzeleithner's argument as it suggests that indigenous peoples, to whom the Convention applies, are peoples in independent countries who are descendants from populations that inhabited the country at the time of conquest or colonization and who retain some or all of their own social, economic, cultural, and political institutions (Article 1.1). This situation implies that indigenous identity, or way of perceiving oneself and others, is not deliberately acquired or rejected (Holzeleithner, 2012, pp. 28).

Bauman also gives us other perspectives on identity. He argues that the idea of identity has been conceived as a social effort to build a bridge between what is and what should be, to bring to reality the ideals of the concept of identity (Bauman, 2004, pp. 20). These bridges, in indigenous communities, are the integrating vision of the human being and his immersion in the large earthly community. Indigenous identity not only includes the human being, but everything that surrounds him: land, air, water, mountains, trees, and animals. Indigenous identity bridges the human being with the natural environment. There is a parameter or principle in the relationship that Latin American indigenous communities have with their environment, especially with natural resources and the otherness. This parameter or principle is called good living ${ }^{4}$ or sumak kawsay (in Quechua). It is a fundamental component of indigenous identity that creates the bond between its being and the universal being: La Pachamama (Cortez, 2011, pp. 7).

In addition, good living emerges as a critical approach to the modern world based on the premise of the human being as a subject, who is equally part of society and part of nature. For Adriana Sánchez, the concept of good living proposes alternative lines of thought on modern development, and has a cross-border political presence (2014, pp. 2) because not only is it an ethnic proposal by and for indigenous peoples (CONAIE, 2007, pp. 2), but also a philosophy that recognizes natural diversity to achieve unity beyond race or nationality. Good living is an expression of genuine indigenous selfdetermination (Altmann, 2019, pp. 76), as it seeks the construction of a plural society through the recognition of different collective memory and knowledge.

3 Derecho de salida, for its reference in Spanish.
4 El buen vivir, for its reference in Spanish 
This concept comes from a philosophy of life (Cresto, 2017, pp. 16) that rescues their knowledge by re-identifying their vision of the world. Based on the right to self-determination, indigenous communities today seek to reinforce their struggles and resistances to fight for their right to control their destiny.

For most native peoples in Latin America, maintaining their culture and idiosyncrasies has been a challenge within the current political and economic system. They defend their ways of thinking and their ancestral wisdom in a world of constant movement, in which cultural negotiation is continuous. The struggle to maintain an explicit indigenous identity has become a crucial instrument for the survival of this culture (Maddinson, 2013, pp. 289). The challenge, then, is to affirm an identity committed to resisting globalization, taking roots in their culture and attachment to the land. Although good living might be interpreted differently by each Latin American indigenous community; it is important to acknowledge that the application of good living is an emancipatory indigenous practice that continuously contributes to the creation of the identity process because it constitutes one of the most powerful expressions of indigenous culture that is profoundly engaged with their land and development.

\subsection{Reconciliation of heterogeneous societies and collective knowledge}

The idea of Latin America was an European notion that eliminated the original denotations given to this land by first peoples. This process was a decultural phenomenon of material and spiritual dispossession. It was also an expression of the colonization of knowledge (Mignolo, 2005, pp. 21). For Mignolo, this situation was the cause of the colonial wound (2005, pp. xii). The colonial wound is the feeling of inferiority imposed on human beings who do not fit into the model predetermined by those who created the classification parameters and granted themselves the right to classify (Mignolo, 2005, pp. 8). The colonial wound is an intergenerational and collective trauma that the victims of colonialism have suffered.

Indigenous repression in Latin America started in the colony in 1492, where more than sixty million indigenous peoples were killed by the colonizer (Pacheco, 2002), producing the colonial wound. This colonial wound is currently reflected in the indigenous struggle to remain visible after centuries of repression of their identity and culture. The problem of the indigenous identity's permanence in the post-colony, leads us to scrutinize historical-social theories capable of responding adequately to structural needs for native cultures and 
their natural environment to survive. To reconciling heterogeneous societies, several proposals aim to protect indigenous identity within social diversity. In these proposals, differences are respected and accepted through customary or political systems that respond to the complexity of the periphery-center relationship. Without attempting to create an exhaustive list of proposals, this essay will delve into interculturality (Mignolo, 2005, 118) and plurinationality (Schavelzon, 2015, pp. 93).

Interculturality has social meanings related to the simultaneous existence of different cultures that respect the way of living and others' epistemological space. Interculturality does not mean to speak with the same logic in two different languages, but to achieve a collaborative conversation using the logic of two different languages for the good of the involved parties (Mignolo, 2005, 118). This narrative coexistence does not reject the being nor the knowledge of others; on the contrary, it agrees to observe an unalike context from a heterogeneous cosmovision. That acceptance of social diversity is the base of inclusion of local stories aimed to reconstruct the coexistence of histories of the colonized and the colonizers. It allows critical analysis on the essence of different perspectives, rather than taking for granted ideas imposed by those who control and controlled power.

Interculturality is the recognition of the heterogeneity of social, economic, cultural, and political conformation for the sake of transforming current ideological structures on a foundation of acceptance and reconciliation. Interculturality can only develop in a framework of equity before the state, the law, and the otherness; where there is mutual respect for difference. It is a tool against the divisions imposed by colonizing ideas that have dispersed the social fabric. Interculturality, finally, becomes a tool for social reconciliation within diversity, pursuing the consolidation of a single society driven by the cooperation, participation, and commitment of all social sectors.

Plurinationality, on the other hand, relates to the system of the state organization. It is the principle that allows all nations within a state to be guaranteed full democratic participation. This principle is based on recognizing all different nations that are part of the same state (Schavelzon, 2015, pp. 93). A nation is understood as a human collectivity that has similar characteristics in terms of culture, idiosyncrasy, interpretation of the world, language, traditions, and territory. In the concept of nation, indigenous communities are included by nature; however, plurinationality is not only circumscribed to these communities, but to all types of nations that inhabit a state. The 
concept of plurinationality causes indigenous nations, who have generally been marginalized, to exercise political participation by including ideas in state life without having to leave their worldview behind.

Plurinationality is a method of reconciliation in the modern world insofar as it advocates for the autonomous development of the cultural and political identity of each of the nations that make up a state. It guarantees the full exercise of civil, political, social, economic, cultural, and environmental rights, consolidating a state guided by the sovereignty of its peoples, the independence from its colonizers, and the democratic system as the best form of community construction. Plurinationality reaffirms unity in difference, does not impose ideas, recognizes the right to territory, the internal political and administrative autonomy of indigenous communities. It is a proposal of reconciliation based on a new form of organization: the construction of a new state with the participation of excluded nations.

Developed around interculturality and plurinationality, good living, has academic and real-life foundations. It becomes an instrument of resistance and reconstruction of the social fabric. Good living constitutes a legitimate path to reconciling today's heterogeneous societies and collective memory through (i) the strengthening of the acceptance for the difference in diverse societies; (ii) the assimilation of its meaning as an integrating and respectful action between human beings and their natural environment; (iii) indigenous political participation in policy-making and rule-making; and, (iv) the full exercise and protection of civil, political, social, economic, cultural, and environmental rights.

Interculturality and plurinationality are two proposals that promote the reconciliation of heterogeneous societies as they might impact decision-making in all State levels, creating inclusive public policies and ethnic rights-oriented judgments. Once implemented in society, these proposals might produce the acceptance of cultural differences and the social inclusion of minorities' ideals such as good living. Interculturality and plurinationality might also contribute to the reconstruction of identity of repressed indigenous peoples as they are the foundation of political participation, which strengthens their vision of the world and, therefore, their way of life. 


\section{Coloniality and development in the modern world}

To frame the notion of good living in a coloniality and a development context, it is necessary to elucidate the concepts related to these topics. This section will define the concepts of coloniality and colonialism; and then, it will establish the modern understanding and application of the concepts of development and underdevelopment.

\subsection{Coloniality and colonialism in context}

For Grosfoguel, colonialism refers to colonial situations imposed by the presence of a colonial administration as in the period of classical colonialism (2010, pp. 74). In turn, the term coloniality is used to address colonial situations in the current period in which colonial administrations have almost been eradicated from the capitalist system (Quijano, 1991, pp. 14). Grosfoguel uses the concept of coloniality of power to refer to a pattern of global and continuous domination (2010, pp. 73) with an effect of economic, political, social, and epistemological domination in the peripheral states.

Schiwy explains that coloniality is three-dimensional (i) it is a situation that encompasses the study of economic and political relationships in the constitutive role of the globalization process, emphasizing the qualitative difference that these relationships have introduced since the conquest of the Americas. (ii) Epistemic relations have given way to a hegemonic order of knowledge that, for many, continue to form the idea of how globalization is thought. And (iii) the construction of subjectivity has been thought as a naturalization of colonial relationships articulated around the idea of race (2010, pp. 273).

After the independence fights of the peripheral states, the colonial legacy remained highlighted by the narratives brought from the global north under the concept of modernity (Mignolo, 2005, pp. 57). This modernity has been, and continues to be, used as a discourse of salvation addressed towards excolonies. Central hegemonies promise to bring modernity and development to ex-colonies if they follow all the economic, political, social, and epistemological instructions given by them (Hickel, 2018). This is considered coloniality of power, the continuity of colonialism: seeking to control marginalized countries and their systems. From the global north view, coloniality of power is a favourable form of intervention for the less developed countries. From the satellite countries, the narrative is the opposite. 
In this context, human relations between the land and indigenous communities in Latin America, have often been governed by ideas and knowledge external to indigenous communities. States of the periphery that achieved their independence have been imposed, liberal discourses regarding the economy, systems of government and relationships between the human being and the environment. According to the coloniality of power (Quijano, 1991, pp. 19), Latin America still lives in a colonial world that needs to be broken to achieve freedom and independence from the economies and pressures from the global north.

\subsection{Developed and developing in context}

Internationally, the origin of development can be traced back to the United Nations Charter (United Nations [henceforth UN], 1945). In the Preamble and in Chapter XI, it referred to the need to promote social progress and raise the standard of living within a broad concept of freedom. This Charter, which creates a link between human rights, and economic and social progress, was of great importance in the emergence of the right to development (Gómez, 1999: 20). Article 55 (a) contains the United Nations' commitment to promoting the right to economic and social development. Nevertheless, according to article 1, the Organization's main purposes are to maintain international peace and security and promote international cooperation among nations. Other purposes, such as promoting social progress, were linked to this goal.

The Universal Declaration of Human Rights (UN, 1948) takes up what was said in the United Nations Charter: promoting social progress and raising the standard of living in a wider margin of freedom. It also raised the need for the satisfaction of economic, social, and cultural rights as a sign of modern development. Besides being the positivization of customary law (O'donnell, 2004, pp. 72), the binding nature of this document was recognized by the final act of the International Conference on Human Rights held in Tehran in 1968 under the auspices of the United Nations. It contains the following proclamation: "The Declaration enunciates a common conception among all peoples of the equal and inalienable rights of all members of the human family and declares it binding on the international community" (1968, para. 2). Although being part of the soft law, today, the legal value of the Universal Declaration might be considered unquestionable, and its provisions on human rights and modern development are a guideline to follow by all states. 
There are several other documents issued by the United Nations and different international organizations addressing the issue of development. Even though they will not be further discussed in this paper, the following Declarations involve the concept of development as a core of their content: The International Covenant on Civil and Political Rights (1976); The International Covenant on Economic, Social, and Cultural Rights (1976); and The Declaration on the Right to Development (1986), among others.

The right to development entails the right of all individuals to have an active, free, and meaningful participation in development and fair distribution of its benefits. It rejected foreign domination, racism, discrimination, and all violations of human rights. It entrusted states with a duty to direct development for the well-being of all people and called on them to work together. The right to development supports people's right to self-determination and sovereignty over their natural wealth and resources. States have not always respected human rights in their development decisions, this has impaired development and contributed to growing inequalities. It has led to decisions that have denied fundamental rights such as food, water and sanitation, adequate housing, education, and health.

Under the idea of development (Constitutional Court, 2012, C1051), the Colombian Government signed the International Convention for the Protection of New Varieties of Plants. Consequently, the Congress issued the implementing Law 1518, 2012. The Convention established a legal protection regime favoring the breeders of new plant varieties, granting them a right to dispose of the variety they create. With the implementation of this regulation, Colombian indigenous communities and their territories, where they develop agriculture, might be directly impacted as the production of plants would be restricted. This situation would affect their relationship with nature and, therefore, their subsistence and identity. The Colombian Constitutional Court (2012, C1051) declared these provisions unconstitutional because there was not indigenous participation in the way of prior consultation during the signing of the Convention process.

In 2019, an emblematic case related to prior consultation in Ecuador took place through a Protection Remedy. A Court of Criminal Guarantees, based in Pastaza County, protected the right to prior consultation of the Waraoni indigenous peoples with a court ruling in case No. 16171201900001. Through this decision the Court ordered, in the first and second instances, that the State must refrain from continuing with the oil extraction project in Waraoní 
territory because it had not complied with the standards for the application of prior consultation (Tribunal de Garantías Penales con sede en el Cantón Pastaza, 2019, pp. 60-104).

Before the Declaration on the Right to Development was issued, development was generally understood in relation to economics and Gross Domestic Product -GDP-. Moreover, even though the development conceptions have changed, states still put a high importance on economic issues. When implementing development projects on indigenous territories, it must be recognized what these communities understand as development. Often, they have more developed relationships with the natural environment, thanks to traditional farming practices and a lack of overconsumption. The same can often be said about community reciprocity and human-to-human relationships. Nevertheless, in many cases, indigenous communities have been threatened, and their identity jeopardized on behalf of development. The most vulnerable and marginalized populations bear the worst part of development policies when they go wrong.

When economic development is equated with economic growth only, it contributes to dominant economies' purposes and dismisses local development of satellite communities. Seeing development exclusively in terms of economic growth produces an engagement with the new form of colonialism. Global North ideologies are being forced upon cultures through the guise of helping them develop (Hickel, 2018). In this perspective, the concept of development becomes a discursive instrument that reflects the evolution from physical colonialism to the coloniality of power. Furthermore, with the direct intervention of developed countries, through externally based development plans, the sovereignty and self-determination of indigenous communities are yielding dangerously.

When used as coloniality of power, the global north discourse of development targets people as objects of study and not as subjects of their own development (Edwards, 2008, pp. 118). And, being defined by only one of the parties involved, the objectives of development and development projects lead to misunderstandings and misapplications in terms of meaning, needs, and how to meet those needs. In indigenous communities, there is a considerable deterioration of the indigenous interpretation of the world because the dispossession of their territories, is a core part of an economic model oriented to the exploitation of the natural resources that they protect, which has stimulated the arrival of foreign investments in the energy, oil, and mining fields mainly (Valladares, 2017, pp. 3). When economic interests 
rise, the indigenous idiosyncrasy and their meaning of development, remain invisible for states and development practitioners.

According to Edwards, development problems must be solved according to the complexity of places and spaces. Native communities cannot be subjected to standard development projects; on the contrary, projects must be implemented with a correct approach to their worldview (2008, pp. 120). In the modern era, there is a need for a strong link between the object and the subject of development where all subjectivities of indigenous communities are to be adequately valued. Development practitioners must acknowledge the community positions of indigenous peoples concerning the world that surrounds them, as well as the economic and social structure of the collectivity, so as not to fall into the error of inefficiently applying theories based on the global-north development ideas.

The incorporation of externally based plans of development over indigenous communities could becomearepresentation of coloniality of power (Stavenhagen, 1963, pp. 64) when not addressed according to targeted beneficiaries. It is not possible to formulate an adequate theory for development, nor a development plan, if the needs and know-how of the targeted population are dismissed. Indigenous communities have their own needs and know-how, which are faithfully linked to good living. Good living deeply shapes the way they relate to the natural environment and to the otherness, so its acknowledgement and protection must be in the front line when speaking of development. Approaching development from the indigenous communities' point of view might improve indigenous lives, allowing them to reach their full potential.

\section{El buen vivir and the indigenous rights to prior consultation and free, prior, and informed consent}

Lives of indigenous populations have remained subjugated to the modern colonial idea (Maddinson, 2013, pp. 288-289), causing structural violence against their ways of thinking and their ways of relating to the outside world. In this modern colonial idea, being indigenous means having and defending an identity in the politicized context of contemporary coloniality (Alfred \& Corntassel 2005, pp. 597). It has been marked by the existence of struggles against material and spiritual dispossession. Indigenous movements in Latin America have engaged with a long process of anti-colonial resistance that has gained visibility since the 1960s (Schiwy, 2010, pp. 182) and has brought us 
to this historical moment in which we seek, once and for all, to end the postcolonialist yoke.

One way to break with the externally imposed colonial relationship between indigenous communities and the natural environment, is the strengthening of indigenous political participation through the implementation of $P C$ and FPIC. These options are alternatives beyond the global north vision of the humannature relationship. Not only are they inscribed in the relationships within and with the land, but also in the production and transmission of indigenous knowledge and culture. The idiosyncrasy of native communities cannot be subjected to external regulations under the penalty of constituting an assault to their existence, their right to self-determination and their right to selfgovernment. Claiming one's own land and identity, claiming the real application of the rights to $P C$ and $F P I C$, supported by good living, is an act of social and cultural consciousness against coloniality.

Modern states have the political and democratic obligation to promote the strengthening of $P C$ and FPIC in order to correctly apply the postulate of good living that reflects the indigenous reality of most Latin American countries. Amongst other measures, states promote this through different gestures of decoloniality such as laws to protect indigenous identity, decrees containing regulatory measures and respect for the worldview of the first peoples, inclusive public policies for all ways of seeing life, effective and efficient legal actions to protect human rights, and relevant education programs in which the guiding axis is the acceptance of diversity. Moreover, as a gesture of decoloniality, good living has recently been integrated into the constitutional systems of some countries of the continent: Ecuador and Bolivia. After incorporating the notion of good living into these constitutions, indigenous political and social participation has considerably increased (Barié, 2014). At the same time, it served as a tool for reconciliation, allowing profound changes in social structures and legal systems.

\section{Prior consultation and Free, informed, and prior consent as a decolonial instrument for indigenous communities in Colombia}

At international level, the Convention No. 169 issued by the International Labour Organization enshrines the right to Prior Consultation. According to it, 
indigenous communities have the right to be consulted before development projects that affect them are carried out on their territories. It also recognizes the right of these communities to decide on their own priorities for development processes that affect their lives, beliefs, institutions, spiritual well-being, and lands they occupy (International Labour Organization, 1989, arts. 6, 15). On the other hand, in 2007, the UN issued the Declaration on the Rights of Indigenous Peoples, it calls for states to consult with indigenous communities through their representatives to obtain prior approval of any project that affects their lands, territories, or other resources (UN, 2007, art. 32.2).

Established in 1991, Colombia's current constitutional system is a pioneer in Latin America for its constitutional recognition of indigenous communities' rights (IACHR, 1993). Among other indigenous rights enshrined in the Constitution, one of particular relevance is the right to prior consultation. The constitutional text stated that the exploitation of natural resources in indigenous territories shall be done without detriment to the cultural, social, and economic integrity of the indigenous communities. The constitutional text forces the Colombian Government to consult indigenous communities on decisions regarding exploiting natural resources on their territories (Asamblea Nacional Constituyente, 1991, art. 330). The Constitutional Court, being the interpreter and guardian of the 1991 Constitution, through its judicial decisions can shape the interpretation of all fundamental rights the Constitution enshrines (López, 2002; Semper, 2006). In this particular case, the Court (2018, SU123) has introduced the right to free, prior, and informed consent as a stronger way of political participation.

According to the Constitutional Court (2019, T063), FPIC applies when there is an intense, direct affectation produced by a measure that threatens the fundamental right to physical or cultural subsistence of the community. By virtue of this right, it is mandatory to obtain free, prior, and informed consent (Constitutional Court, 2018, T123) in the following cases:

1. Transfer or relocation of the indigenous or tribal people from their place of settlement.

2. The storage or deposit of dangerous or toxic materials in their territories.

3. Measures that imply a high social, cultural and environmental impact that might jeopardize their subsistence.

In prior consultation, the results of the consult are not binding for the State. The State can continue with the project implementation if it considers it is 
relevant to the country. In this case, the State is forced to provide sufficient and objective reasons for not attending the consultation results. On the other hand, in free, prior, and informed consent, obtaining consent is mandatory in the three referred cases. The scope of FPIC implies that the State only has the power to implement the measure if it obtains free, prior, and informed consent from the indigenous community. The consent of the diverse ethnic people is binding, as without it, the implementation of the measure implies a violation of these ethnic groups' rights (Constitutional Court, 2018, SU123). Also, in Judgments T294, 2014 and T576, 2014, the Constitutional Court pointed out the need to carry out prior consultation and even obtain the free, prior, and informed consent of the communities before approving any large-scale development or investment plan with a substantial impact on the territory of ethnic communities, particularly concerning the use or exploitation of minerals, water, or other resources.

If the State seeks to implement a measure in pursuit of development within an indigenous territory, indigenous participation must be guaranteed through PC and FPIC (Constitutional Court, 2019, 063). Indigenous peoples, exerting their right to political participation, must let the State know what their concept of development is in order to determine the feasibility of the project in their territories. In Judgment T428, 1992, the Constitutional Court clarified that development cannot be based on individual harm, even if it is a minority or even if it is one person. The protection of fundamental rights does not depend on the general interest; those are regulations that contain an absolute value, which cannot be negotiated or underestimated. The vision of development of the indigenous peoples is not the same as that of the culture outside this population; for this reason, it is not possible to impose a vision of general development over these particular communities.

Given the democratic and participatory nature of the State, the concept of development must be related to alternative projects of coexistence and good living, beyond the parameters provided by the logic of the market (Constitutional Court, 2016, T197). In this context, PC and FPIC promote a genuine and intercultural dialogue with indigenous communities. Such dialogue implies that the participation is not complete only notifying decisions to people involved or holding informative meetings, but rather to adopt measures so that the community can defend their idea of development. This is why the Constitutional Court (2019, T063) stated that the process to implement the participation must be flexible so that it adapts to the needs of the peoples' diversity. 
Based on this argument, the Court included the concept of dialogic constitutionalism, which is framed in considering general levels of inclusion in response to social demands (Constitutional Court, 2017, C 041) Under a decolonial idea, dialogic constitutionalism recreates the concept of collective memory and tradition based on interculturality and the inclusion of diverse ways of thinking. It strengthens a constitutional culture that seeks to banish times of violence or contempt for others' lives and enforce the minimum guarantees given to every human being for the mere fact of existing.

Besides, the Court calls for intercultural dialogue, defined as one of the possible forms of approach amongst different cultures, especially in scenarios that have lived colonialism, as it occurred in Colombia. Intercultural dialogue includes the improvement of the quality of life according to the principles that are originated in good living. The Court also argues that being Colombia a plurinational State, intercultural dialogue implies the respect of indigenous participation and the good living of ethnic communities (Constitutional Court, 2015, C 041). In constitutional judicial scenarios, Colombia has started to implement the concepts of plurinationality and interculturality, so that ethnic communities are guaranteed the rights to PC and FPIC; therefore, their political participation favours their self-determination and self-governance (Constitutional Court, 2016, T 213).

The debate around development in the territories of indigenous peoples, must be analyzed in light of their concept of development. It is essential to balance the recognition of the otherness and the other different visions of development by indigenous communities that are part of the interculturality and the plurality of the State. Indigenous participation, through the exercise of $P C$ and FPIC, allows indigenous peoples to maintain their way to see the world and good living, while at the same they can recreate their own concept of development. It is high time to acknowledge that Latin America is the result of its continued participation in the process of world capitalist development (Gunder, 1966, pp. 21) and that PC and FPIC constitute powerful instruments to start to decolonize the imposed concept and process of development. In the end, development is about processes of enrichment, empowerment, and participation (Edwards, 2008, pp. 120); therefore, indigenous participation and good living strengthens the indigenous identity, collective memory, and their active, free, and meaningful participation in development. 


\section{Conclusions}

Acknowledging that the concept and scope of good living might vary from one indigenous community to another, this paper highlights the importance of opening social and political spaces to generate a debate on the meaning and implications of the concept. It is essential to understand the role good living plays in scenarios of political participation, such as in prior consultation and free, prior, and informed consent to frame its application according to indigenous needs. This paper raises more questions than answers; particularly, this essay identifies the need of field-research to study indigenous postulates and how to implement them in policy-making and decision-making processes, to contribute to a more inclusive society.

For most native peoples in Latin America, maintaining their culture and idiosyncrasies has been a challenge within the current political and economic system. They defend their ways of thinking and their ancestral wisdom in a world of constant movement, in which cultural negotiation is continuous. The struggle to maintain an explicit indigenous identity has become a crucial instrument for the survival of this culture (Maddinson, 2013, pp. 289). The challenge, then, is to affirm an identity committed to resisting globalization, taking roots in their culture, and attachment to the land. Although good living might be interpreted differently by each Latin American indigenous community; it is important to acknowledge that the application of good living is an emancipatory indigenous practice that continuously contributes to the creation of the identity process, because it constitutes one of the most powerful expressions of indigenous culture that is profoundly engaged with their land and development.

Developed around interculturality and plurinationality, good living, has academic and real-life foundations. It becomes an instrument of resistance and reconstruction of the social fabric. Good living constitutes a legitimate path to reconciling today's heterogeneous societies and collective memory through (i) the strengthening of the acceptance for the difference in diverse societies; (ii) the assimilation of its meaning as an integrating and respectful action between human beings and their natural environment; (iii) the indigenous political participation in policy-making and rule-making; and, (iv) the full exercise and protection of civil, political, social, economic, cultural, and environmental rights.

Interculturality and plurinationality are two proposals that promote the reconciliation of heterogeneous societies as they might impact decision-making in all State levels, creating inclusive public policies and ethnic rights-oriented 
judgments. Once implemented in society, these proposals might produce the acceptance of cultural differences and the social inclusion of minorities' ideals such as good living. Interculturality and plurinationality might also contribute to the reconstruction of identity of repressed indigenous peoples as they are the foundation of political participation, which strengthens their vision of the world and, therefore, their way of life.

The incorporation of externally based plans of development over indigenous communities could becomearepresentation of coloniality of power (Stavenhagen, 1963, pp. 64) when not addressed according to targeted beneficiaries. It is not possible to formulate an adequate theory for development, nor a development plan, if the needs and know-how of the targeted population are dismissed. Indigenous communities have their own needs and know-how, which are faithfully linked to good living. Good living deeply shapes the way they relate to the natural environment and to the otherness, so its acknowledgement and protection must be in the front line when speaking of development. Approaching development from the indigenous communities' point of view might improve indigenous lives, allowing them to reach their full potential.

The debate around development in indigenous peoples must be analyzed in light of their concept of development. It is essential to balance the recognition of the otherness and the other different visions of development by indigenous communities that are part of the interculturality and the plurality of the State. Indigenous participation, through the exercise of $P C$ and FPIC, allows indigenous peoples to maintain their way to see the world and good living, while at the same time, they can recreate their own concept of development. It is high time to acknowledge that Latin America is the result of its continued participation in the process of world capitalist development (Gunder, 1966, pp. 21) and that $P C$ and FPIC constitute powerful instruments to start to decolonize the imposed concept and process of development. In the end, development is about processes of enrichment, empowerment, and participation (Edwards, 2008, pp. 120); therefore, indigenous participation and good living strengthens the indigenous identity, collective memory, and their active, free, and meaningful participation in development. 


\section{References}

Alfred, T. \& Corntassel, J. (2005). Being indigenous: resurgences against contemporary colonialism. Government and Opposition. (Vol. 40, No. 4, pp. 597-614).

Altmann, P. (2019). Los pueblos indígenas en el buen vivir global, un concepto como herramienta de inclusión de los excluidos. Iberoamerican Journal of Development Studies. (Vol. 8, No. 1, pp. 58-80).

Asamblea Nacional Constituyente de Colombia. (1991). Gaceta Constitucional de 1991 No. 116, July 20, 1991.. Bogotá.

Barié, Cletus (2014). Nuevas narrativas constitucionales en Bolivia y Ecuador: el buen vivir y los derechos de la naturaleza. Revista de Estudios Latinoamericanos. (Vol. 59, pp. 9-40).

Bauman, Z. (2004). Identity. Conversations with Benedetto Vecchi. London, United Kingdom: Polity Press Publisher.

Colombian Constitutional Court. (2011). Judgment T129. [M.P. Jorge Iván Palacio Palacio]

Colombian Constitutional Court (2012). Judgment C1051. [MP. Luis Guillermo Guerrero Pérez]

Colombian Constitutional Court. (2013). Judgment T 359. [M.P. Jorge Iván Palacio Palacio]

Colombian Constitutional Court. (2015). Judgment C 041, Clarification of vote by Maria Victoria Calle Correa. [M.P. Jorge Iván Palacio Palacio]

Colombian Constitutional Court. (2016). Judgment T 445. [M.P. Jorge Iván Palacio Palacio]

Colombian Constitutional Court. (2016). Judgment T 197. [M.P. Jorge Iván Palacio Palacio]

Colombian Constitutional Court. (2016). Judgment T 213. [M.P. Jorge Ignacio Pretelt Chalhub]

Colombian Constitutional Court. (2017). Judgment C 041. [M.P. Ariel Eduardo Mendoza Martelo \& Jorge Iván Palacio Palacio]

Colombian Constitutional Court. (2018). Judgment SU123. [M.P. Alberto Rojas Ríos \& Rodrigo Uprimny Yepes]

Colombian Constitutional Court. (2019). Judgment T063. [M.P. Antonio José Lizarazo Ocampo]

Confederación de Nacionalidades Indígenas del Ecuador -CONAIE- (2001). ¡Llacta! -Proyecto Político. Approved in the I Congreso Nacional de las Nacionalidades y Pueblos Indígenas del Ecuador. Retreived December 9, 2019, from http://www.llacta. org/organiz/coms/com862.htm

Cortez, D. (2011). La construcción social del "Buen Vivir" (Sumak Kawsay) en Ecuador. Genealogía del diseño y gestión política de la vida. Revista de la Universidad Andina Simón Bolivar. (Pp. 1-23).

Crespo, J. (2017). Del Sumak Kawsay al Buen vivir. In Greene, N., \& Larrea, C. (Ed) Buen vivir como alternativa al desarrollo: una construcción interdisciplinaria y participativa (pp. 12-26). Quito: Universidad Andina Simón Bolívar.

Ecuador. Tribunal de Garantías Penales con sede en el Cantón Pastaza (2019). Pueblo indígena Waraoní Vs. Estado de Ecuador. First instance sentence. Trial No. 16171201900001.

Edwards, M. (2008). The irrelevance of development studies. In Chari, S., \& Corbridge, S. (Ed), The Development Reader (pp. 305-311). New York: Routledge.

Escobar, A. (2007). La invención del tercer mundo, construcción y deconstrucción del desarrollo. Caracas: Fundación editorial el perro y la rana. 
Gómez, Felipe (1999). El derecho al desarrollo como derecho humano en el ámbito jurídico internacional. Bilbao, España: Universidad de Deusto.

Grosfoguel, R. (2010). The epistemic decolonial turn: beyond political-economy paradigms. In Escobar, A., \& Mignolo, W. (Ed), Globalization and the decolonial option (pp. 65-77). New York: Routledge.

Gunder, A. (1966). The Development of Underdevelopment. Monthly Review. (Vol. 18, No. 4, pp. 17-51).

Hartwick, E., \& Peet, R. (2015). Theories of Development, contentions, arguments, and alternatives. New York: The Guildford Press.

Hickel, J. (2018). The Divide, Global Inequality from Conquest to Free Markets. New York: Norton \& Company, Inc.

Holzleithner, E. (2012). Interrogating Exit in Multiculturalism Theorizing: conditions and limitations. In Borchers, D., \& Vitikainen, A. (Eds), On Exit: interdisciplinary perspectives on the rights of exit in liberal multicultural societies. Walter de Gruyter: Berlin.

Houtart, F. (2011). El concepto de Sumak kawsay (buen vivir) y su correspondencia con el bien común de la humanidad. Revista de Filosofía. (Vol. 69, No. 3, pp. 7-33).

Inter-American Commission of Human Rights. (2009). Indigenous and Tribal people's rights over their ancestral lands and natural resources. Washington D.C.: Organization of American States.

Maddinson, S. (2013). Indigenous identity, 'authenticity' and the structural violence of settler colonialism. Revista Identities: Global Studies in Culture and Power. Vol. 20, No. 3, pp. 288-303.

Mahecha, A., \& Mazuera, P. (2017). Las leyes de los reinos de las indias. Revista Diálogos de Saberes. Bogotá: Universidad Libre de Bogotá.

Mignolo, W. (2005). The Idea of Latin America. Oxford: Blackwell Publishing.

Mignolo, W. (2006). Evo Morales en Bolivia: ¿giro a la izquierda o giro descolonial?. In Da Cruz, J. (Ed.), Democracias en Desconfianza. Ensayos en sociedad civil y política en América Latina (pp. 93-106). Montevideo: Editorial Coscoroba.

Muñoz, C. (2019). Bolivia, la Reelección Presidencial Ilimitada y el paradigma de la Seguridad Jurídica Constitucional. Revista de Derechos Humanos y Humanitario. (No. 4, pp. 1-22)

O'donnell, D. (2004). Derecho internacional de los derechos humanos. Normativa, doctrina y jurisprudencia de los sistemas universal e interamericano. Bogotá D.C., Colombia: Oficina del Alto Comisionado para Naciones Unidas para los Derechos Humanos.

United Nations, Charter of the United Nations, 1945, available at: https://www.un.org/en/ about-us/un-charter

International Labor Organization, Convención 169 sobre pueblos indígenas y tribales, 1989. 76th Conference: Geneva, Switzerland.

Pacheco, Ricardo (2002). 60 millones, los indígenas muertos tras la conquista. https:// www.cronica.com.mx/notas/2002/24297.html

Quijano, A. (1991). Colonialidad y Modernidad/Racionalidad. Revista Perú Indígena. Vol. 29, pp. 11- 21.

Salomón, E., \& Feliciano, M. (2019). El buen vivir y el desarrollo desde la perspectiva del pueblo Mayangna, Nicaragua. Journal Universitaria del Caribe, Vol. 21, No. 2., pp. 118-121.

Sachar, A. (2001). Multicultural Jurisdictions. Cultural Differences and Women's Rights. Cambridge University Press. 
Sánchez, A. (2014). Autodesarrollo y buen vivir: el papel de los pueblos indígenas latinoamericanos en la resignificación del desarrollo. Journal Electrónica Iberoamericana, Vol. 8, No. 2. 2014, pp. 1-26.

Schavelzon, S. (2015). Plurinacionalidad y Vivir Bien/Buen Vivir. Dos conceptos leídos desde Bolivia y Ecuador post-constituyentes. Quito: Ediciones Abya-Yala.

Schiwy, F. (2010). Decolonization and the question of subjectivity. In Escobar, A., \& Mignolo, W. (Ed.), Globalization and the decolonial option (pp. 65-77). New York: Routledge.

Stavenhagen, R. (1963). Clases, colonialismo y aculturación. Revista América Latina, Centro Latinoamericano de Investigaciones en Ciencias Sociales. Vol. 6, No. 4, pp. 63-104).

UN General Assembly, Universal Declaration of Human Rights, 10 December 1948, 217 A (III). Paris, France.

UN General Assembly, Declaration on the Granting of Independence to Colonial Countries and Peoples, 14 December 1960, 1514 (VX). New York, United States.

UN General Assembly, Special Fund and the Expanded Programme of Assistance into a United Nations Development Programme, 22 November 1965, 2029 (XX). New York, United States.

UN General Assembly, Declaration on the Rights of Indigenous Peoples, 13 September 2007, A/RES/61/295.

Valladares, L. (2017). El despojo de los territorios indígenas y las resistencias al extractivismo minero en México. In Chenaut, V., \& Valladares de la Cruz, L. (Eds.), Etnicidad, territorio y pueblos indígenas: paradojas y desafíos de las políticas neoliberales, e-cadernos CES. No. 28. (pp. 1-26). 